Békés Enikő nagyívü tanulmánykötetének újdonsága, hogy az interdiszciplinaritás jegyében nem csupán Galeottónak a De doctrinában megmutatkozó felfogását mutatja be, hanem az auktor portréjának részleges megfestése során ő maga is alkalmazza az egyes tudományterületek (filozófia, fiziognómia, asztrológia, orvoslás, stb...) összekapcsolását, amellyel tovább árnyalja a szerzőről kialakult képet. Jelentős eredménye továbbá, hogy a korábbi szakirodalom által másod-élvonalbelinek, ,Mátyás király udvari bohócának" tartott Galotto Marzio szerepét újradefiniálja, és bebizonyítja, hogy a reneszánsz auktornak, Janus barátjának és Guarino tanítványának a természetfilozófiai gondolkodásban, az orvoslásban és az asztrológiai tanok közvetítésében sokat köszönhet a reneszánsz irodalomtörténet és a magyarországi latinság.

\section{DALlOUL ZAYNAB}

Gömöri György, A rejtőzködő Balassi, Ariadné könyvek, Kolozsvár, Korunk Komp-press, 2014, 219 p.

Gömöri György lengyel vonatkozású írásai tanulságos forrásfeltárások: szóljanak akár Jan Sienieńskinek a Balassákkal összefonódó életútjáról, akár a Balassa János halálára epicédiumot író Jan Bielskiről, akár Bekes Lászlóról, aki levélben számolt be - eddig egyetlen ilyen lengyelországi forrást ismerünk - Balassi Bálint haláláról, akár Balassi Bálint és Wesselényi Ferenc kapcsolatáról, akár az 1590-ben Balassi (lengyel pénzen felfogadott) kisebb lovas hadseregéről, akár Sebastian Grabowieckiről. Ezek a kötet kiemelkedően legjobb írásai.

Tény, hogy Gömöri kutatásai nélkül lényegesen kevesebbet tudnánk Balassi utolsó lengyel útjáról is, kiváltképpen a költő itteni kapcsolati hálójáról. Ugyanakkor az is tény, hogy a szerző esetenként ragaszkodik olyan régebbi szakirodalmi megállapításhoz (Eckhardt), amely kevésbé valószínű, mint pl. Célia és Wesselényiné Szárkándy Anna azonosítása. Az ilyen érvek nehezen vehetők komolyan: „Wesselényiné Szárkándi Anna (Bekes Gáspár özvegye) abban a korban lehetett, amikor az asszonyok kettőzött érdeklődéssel reagálnak minden férfi figyelmére - s hogyan állhatott volna ellent a férfias, művelt, ráadásul személyes versekben magasztaló magyar vendégnek?” A kérdésnek később a szerző egy egész tanulmányt szentel (Anna örök, azaz még egyszer Balassi Bálint Céliájáról), amelyben egy általam felállított hipotézist vitat.

Nem szeretném a szerepeket összecserélni: recenziót írok, nem vitairatot. Minden eltérő véleményt tiszteletben tartva, úgy gondolom, Célia személyét kellő bizonyossággal sem Eckhardtnak, sem nekem, sem másnak nem sikerült kideríteni, hipotézisek vannak, ezek közül a Célia = Szárkándy Anna kevésbé valószínü. Az sem bizonyítható, hogy a Célia-versek mind Lengyelországban íródtak volna. Gömöri véleménye egyébként mintha változna a kérdésben. Míg két, időben korábbi cikkében egyértelműen a fenti azonosítást és a Célia-versek lengyelországi genezisét vallja, könyvemről írt (e kötetbe beválogatott) megtisztelően dicsérő hangvételü recenziójában már engedékenyebb: „Másrészt az a tény, hogy a Célia-versek egy része már Balassi Lengyelországba menetele előtt íródott (...)" (193) nyilván nem ugyanaz, mint hogy: ,(...) szinte bizonyosra vehető, hogy a Célia-versek igenis Lengyelországban születtek.” (93)

A Balassa-kódex 138-139. oldalán található egy BÁTHORI akrosztichonú, majd közvetlen utána, a 140-141. oldalon a Segétségül hilak téged incipitü vers. Eckhardt egyiket sem vette fel a Balassi kritikai kiadásba, megoldását máig konszenzus övezi. Gömöri feltételezi, hogy az első vers Balassié, a második esetleg Báthory András bíborosé. Elképzelhető, de - Gömöri is így gondolja - nem bizonyítható.

Sir Philip Sydney magyarországi kapcsolatairól tudhatók nagy részét is a szerző kutatásainak köszönhetjük. Különösen érdekes (akár csak a lengyel viszonyokról szóló tanulmányban) a kapcsolati hálók felrajzolása, Bécs-Itália-Erdély korabeli értelmiségi elitjének (a Páduát járt protestáns humanistáknak) sajátos összefonódása. Languet egy Sydneynek írt, latin nyelvü leveléből Gömöri értékes adatot bont ki: Sydney ismerte Balassa Jánost, s talán fiát, Balassi Bálintot is.

Purkircher György Sidneyhez intézett leve- 
lében ír arról, hogy a törökök keresztény emberáldozattal fékezték meg az elemek erőit. Gömöri szerint „,nagyon is valószínű, hogy ez lett egyik kiindulópontja a Kömíves Kelemen címü népballadában leírt történetnek". Ez igen fantáziadús következtetés. „Az, hogy a hordóba rakott rácból hogyan lett az egyik kőmüves felesége, nem szükséges magyaráznunk: egy ilyen „romantikus” csere nélkül talán nem is lehetett volna ebböl a különös eseményből hátborzongató népballada" - írja Gömöri. Hát, ezzel a mód szerrel sok minden bebizonyítható lenne. A szerző is érezheti ezt, hiszen tanulmánya záró bekezdésében így összegez: „Lehet, persze, hogy (...) a ballada és a temesvári emberáldozat közötti hasonlóság merőben véletlen."

Lengyel nyelvtudás hiányában nem tudok érdemben hozzászólni a kötet egyik legérdekesebb írásához, amely Balassi verseit és a korabeli lengyel költészetet hasonlítja össze.

Gömöri több izgalmas felfedezést tett, amelyeket jelen kötetébe is beválogatott: ő találta meg Balassi Bálint bejegyzését Stephan Haymb emlékkönyvében, ugyancsak ö fedezte fel Hans von Braun albumában a Balassi-címert és Balassi Bálint jelmondatát, ő ismertette a strasbourgi akadémián tanuló 16 . századi magyarok albumbejegyzéseit.

Meggyőző a ,póka” = ,ifjú nő” szófejtés.

Campion (Campianus) müvéről, a szerzőről, a történeti körülményekről, továbbá Balassi találkozásáról a szöveggel valószínüleg Gömöri írta a legalaposabb tanulmányt.

A könyvet két szép vers zárja: a Balassi Krakkóban és a Zrínyi Miklós Balassi Bálintra emlékezik. Tudjuk, Gömöri 1956 novemberében hagyta el az országot. Hihetnénk: az előbbi vers önéletrajzi ihletésű is, hiszen „minden, minden hiába / idegenben nem élhet”. Ám a vers három évvel korábbi (1953. november), meglehet, jövőbelátó...

Sajnálatos hiányosság, hogy a nincsenek lábjegyzetek, nehézkes egy-egy vonatkozás kedvéért a tanulmány végére lapozni. Továbbá, s ez sokkal fontosabb, a kötet nem tartalmaz névmutatót, amely egy ilyen, tudományos értékü kiadványnál nélkülözhetetlen segédeszköz lenne.

KöSZeghy PÉTER
Medialisierung des Zerfalls der Doppelmonarchie in der deutschsprachigen Regionalperiodika zwischen 1880 und $1914, \mathrm{Hg}$. Zoltán Szendi, Wien, LIT Verlag, 2014, 184 p. (Transkulturelle Forschungen an den Österreich-Bibliotheken im Ausland Bd. 9)

Az Európát később teljesen átalakító I. világháború kitörésének 100. évfordulója a legkülönbözőbb tudományos szempontú vizsgálódásokhoz kínál apropót. A sorozat legutóbb megjelent kötete azon nemzetközi kutatások eredményeit foglalja össze, amelyek a Monarchia utolsó békés évtizedeinek német nyelvű helyi sajtójára irányultak. A munkának az volt a célja, hogy a helyi lapok olyan szimptomatikus jelenségeit mutassa be, amelyek elöre jelezték a Monarchia felbomlását. Ismeretes a sajtó véleményformáló ereje, a politikai hatalom birtokosai már akkor is tudták az újságolvasókat - persze nem a mai mértékben - manipulálni. A kötet címében szereplő évszámok arra utalnak, hogy az 1880-as évek egyrészt a Monarchia virágkorát jelentik, másrészt már magukban hordozták a széthullás előjeleit. A kutatás lezáró éve a háború kitörésének éve. A helyi sajtó alkalmas arra, hogy felfedezhessük benne a növekvő nacionalizmus, de ugyanakkor az uralkodó iránti lojalitás, a Monarchia egységének megőrzésére való törekvés nyomait is. A kor legfontosabb kérdéseinek vizsgálatára a legalkalmasabbak az újságok vezércikkei, de a tudósítások, kommentárok, eszszék, valamint a szépirodalmi szövegek is fontos információkat tartalmaznak. A vizsgált helyi lapok hat mai országból származnak, profiljuk különböző volt, többségük német nyelvűsége ellenére eltérő nyelvi és társadalmi közegben létezett.

Gabriele Melischek bevezető tanulmányában a média feladatait vázolja fel krízis-, illetve feszültségszituációk esetén. Miután meghatározza, hogy az identitás mit jelent és melyek a sajátosságai (stabilitás, ugyanakkor dinamizmus és változás is), bevezeti a „framing” fogalmát és bemutatja, mi a funkciója a hírszolgáltatás terén. Ezután tér ki a krízis meghatározására. Az irodalom sajtóbeli terjesztésének példájaként két nagy liberális orgánum, a bécsi Neue Freie 